Wilnie i Zagrzebiu. W ostatniej kadencji władz Międzynarodowej Unii Geograficznej J. Wyrzykowski jest stałym członkiem Komisji Geografii Turyzmu.

Jerzy Wyrzykowski

\section{Geografia turyzmu w Uniwersytecie Warszawskim Zakład Geografii Turyzmu i Rekreacji}

Początki geografii turyzmu na Uniwersytecie Warszawskim sięgają wczesnych lat 60 . W tym czasie Maria I. Mileska opublikowała wyniki swoich badań nad regionalizacją turystyczną Polski. Kolejnymi osobami - spośród geografów - które interesowały się turystyką i rekreacją byli Alicja Krzymowska-Kostrowicka i Michał Stalski. Zajmowali się oni - podobnie, jak wcześniej Mileska - planowaniem turystycznym i ekologia turystyczną. Pierwszy okres zakończył się mniej więcej pod koniec lat 70 .

W 1980 r. Alicja Krzymowska-Kostrowicka opublikowała książkę Terytorialny system rekracyjny. Analiza struktury i charakter powiqzań. Książka ta była rezultatem badań teoretycznych i praktycznych. Krzymowska-Kostrowicka byla pierwsza osobą w Polsce, która zastosowała w praktyce podejście systemowe $w$ geografii turyzmu. W następnej dekadzie prowadziła nadal tego rodzaju badania. W tym okresie powstały jej opracowania teoretyczne The system approach in modelling recreation (1984) i Tourist regions and erritorial recreational system (1986), a także wiele ekspertyz i wskazówek praktycznych dla planistów, administracji parków narodowych oraz władz lokalnych. W tym czasie głównym problemem w jej badaniach był wpływ bioklimatu i roślinności na turystykę i rekreację. Wyniki tych badań zostały opublikowane w $1992 \mathrm{r}$. w artykule Assessment of therapeutical values of natural environment for recreational needs. A case study of Warsaw environs. W roku 1997 Krzymowska-Kostrowicka wydała swoje główne dzieło w tej sferze jej zainteresowań - Geoekologia turystyki $i$ wypoczynku. W następnych latach książka ta wywarła wielki wpływ na innych geografów i specjalistów z zakresu nauk o środowisku zajmujących się turystyką i rekreacją.

W 1988 r. prof. A. Krzymowska-Kostrowicka zorganizowała na Wydziale Geografii i Studiów institutes but also with universities in Brno, Lille, Lyon, Lvov, Minsk, Munich, Oradea, Pullman (USA), Vienna, Vilnius and Zagreb. In the last term of office of the International Geographical Union Prof. Wyrzykowski is a permanent member of the Tourism Geography Committee.

Jerzy Wyrzykowski

\section{Geography of tourism at Warsaw University Department of the Geography of Tourism and Recreation}

The beginnings of tourism geography at Warsaw University date back to the early 1960s. At that time Maria Mileska published the results of her research on the tourist regionalisation of Poland. Other geographers who were interested in tourism and recreation were Alicja Krzymowska-Kostrowicka and Michał Stalski, and both of them, as Mileska before, were interested in tourism planning and tourism ecology. This initial period ran approximately until the end of the 1970s.

In 1980 Alicja Krzymowska-Kostrowicka published her book 'The spatial recreational system: an analysis of the structure and character of relations' (in Polish) resulting from both theoretical and practical studies. Krzymowska-Kostrowicka was the first in Poland to actually use a systems approach in tourism geography. In the next decade she continued similar studies publishing theoretical articles such as 'The systems approach in modelling recreation' (1984) and 'Tourism regions and the spatial recreational system' (1986), as well as giving many expert opinions and practical suggestions for planners, national park administrations, and local authorities. At that time the main topic of her research was the influence of bioclimate and vegetation on tourism and recreation. The results of these studies were published in 1992 in an article 'Assessment of the therapeutical value of the natural environment for recreational needs: the case study of the surroundings of Warsaw'. In 1997 Krzymowska-Kostrowicka published her major work in this field, i.e. The geoecology of tourism and recreation' (in Polish). In the years to follow this book has had a great impact on other geographers and environmentalists interested in tourism and recreation.

In 1988 Prof. Alicja Krzymowska-Kostrowicka organised a specialisation of tourism geo- 
Regionalnych specjalizację $\mathrm{z}$ zakresu geografii turyzmu. W tym czasie zaczęła ona współpracować z Andrzejem Kowalczykiem, który zajmował się rekreacją $\mathrm{w}$ miastach i na terenach podmiejskich. W 1994 r. opublikował on książkę Geograficzno-spoleczne aspekty zjawiska drugich domów, ale w końcu lat 90. zmienil swoje zainteresowania w kierunku geografii turyzmu. W roku 2000 wydał książkę Geografia turyzmu, a w 2001 Geografia hotelarstwa. (W latach 90. współpracowali z prof. Krzymowską-Kostrowicką w zakresie geografii turyzmu również doktorzy: Andrzej Jasiński, Hanna Cetnarska, Leszek Butowski i Barbara Pisarska).

Od 2004 r. - kiedy prof. A. Krzymowska-Kostrowicka przeszła na emeryturę - odpowiedzialnym za specjalizację geografia turyzmu jest prof. A. Kowalczyk. Od 2006 r. na Wydziale Geografii i Studiów Regionalnych jest Zakład Geografii Turyzmu i Rekreacji. Profesor A. Kowalczyk (zajmujący się metodologią geografii turyzmu, planowaniem turystycznym, turystyką kulturowa) jest kierownikiem Zakładu. Pracownikami w Zakładzie na początku 2008 r. są: dr Małgorzata Durydiwka (turystyka wiejska, turystyka sportowa), dr Joanna Przybyś (turystyka kulturowa, turystyka biznesowa, przedsiębiorczość i marketing w turystyce), dr Mikołaj Madurowicz (turystyka kulturowa, turystyka miejska, symbolika turystyczna), dr Sylwia Kulczyk (ekoturystyka, turystyka przygodowa), mgr Marta Derek (polityka turystyczna, planowanie turystyczne) i mgr Katarzyna Duda-Gromada (turystyka wodna, planowanie turystyczne).

Andrzej Kowalczyk

\section{Geografia turyzmu w Uniwersytecie Lódzkim Instytut Geografii Miast i Turyzmu}

Badania geograficzne nad turystyką rozpoczęto w Lodzi w okresie międzywojennym. Miały one wówczas głównie charakter użytkowy (Atlas krajoznawczy, 1923, Przewodnik turystyczny po Lodzi i okolicy, 1939). Po utworzeniu w 1945 r. Uniwersytetu Łódzkiego podjęto badania nad klimatem i bioklimatem uzdrowisk polskich i kontynuowano prace nad mapami krajoznawczo-samochodowymi oraz przewodnikami turystycznymi. Pierwszą jednostką organizacyjną zajmującą się turystyka, głównie jednak dydaktycznie, było powołane graphy in the Department of Geography and Regional Studies and began to co-operate with Andrzej Kowalczyk who had been interested in recreation in towns and cities and the areas surrounding them. In 1994 he published a book 'Socio-geographical issues of second homes' (in Polish), but in the late 1990s he shifted his interest towards tourism geography. In 2000 he published 'Tourism geography' (in Polish) and in 2001 'Geography of the hotel industry' (in Polish). [Other scholars who cooperated in the 1990s with Prof. Krzymowska-Kostrowicka in the field of tourism geography were Dr Andrzej Jasiński, Dr Hanna Cetnarska, Dr Leszek Butowski, and Dr Barbara Pisarska]

Since 2004, when Prof. Krzymowska-Kostrowicka went into retirement, Prof. Andrzej Kowalczyk has been responsible for the specialisation of tourism geography. In 2006 a Department of the Geography of Tourism and Recreation was started in the Department of Geography and Regional Studies. Prof. Andrzej Kowalczyk (methodology of tourism geography, tourism planning, cultural tourism) is the Head of Department. At the beginning of 2008, the other members of the department were: Dr Małgorzata Durydiwka (rural tourism, sports tourism), Dr Joanna Przybyś (cultural tourism, business tourism, tourism enterpeneurship and marketing), Dr Mikołaj Madurowicz (cultural tourism, urban tourism, tourism symbols), Dr Sylwia Kulczyk (ecotourism, adventure tourism), Marta Derek M.A. (tourist policy, tourism planning), and Katarzyna Duda-Gromada, M.A. (water tourism, tourism planning).

\section{Andrzej Kowalczyk}

\section{Geography of tourism at the University of Eódź Institute of the Urban Geography and Tourism}

The geographical study of tourism in Łódź started in the inter-war period. It mainly had a practical character then (Atlas Krajoznaw czy - Tourist Atlas (1923); Przewodnik turystyczny po Łodzi i okolicy - Tourist Guide to Łódź and its Surroundings - 1939). In 1945, after the University of Łódź had been founded, studies of the climate and bioclimate of Polish spas were started, as well as work on tourist-road maps and tourist guidebooks.

The first organised unit dealing with tourism, mainly in the didactic sense, was the Post- 